Arab World English Journal (AWEJ) Volume 12. Number1 March 2021

DOI: https://dx.doi.org/10.24093/awej/vol12no1.18

Pp.253-269

\title{
The Effects of Vocabulary Self-Collection Strategy Instruction on Thai EFL Undergraduate Students' Vocabulary Knowledge and Perceptions
}

\author{
Nuntiporn Raungsawat \\ Language Institute, Thammasat University \\ Bangkok, Thailand \\ Correspondent Author: nun.raung@gmail.com \\ Tipamas Chumworatayee \\ Language Institute, Thammasat University \\ Bangkok, Thailand
}

Received: $12 / 26 / 2020$

Accepted: 2/22/2021

Published: 3/24/2021

\section{Abstract}

This study mainly examines the effect of Vocabulary Self-Collection Strategy (VSS) instruction on students' vocabulary knowledge. Moreover, it investigates the students' perceptions towards the implementation of VSS instruction. Thirty-eight Thai EFL undergraduate students majoring in English at a university located in Thailand participated in the study. To determine the students' vocabulary knowledge before and after the instruction, the vocabulary pretest and posttest were employed. A perception questionnaire and a semi-structured interview were conducted at the end of VSS instruction to elicit the students' perceptions towards VSS instruction. The paired samples $t$-test analysis indicates that the students improved short-term vocabulary retention, and they could retain vocabulary learned after VSS instruction. The results from the questionnaire and the semi-structured interview showed that they mostly agreed that VSS instruction assisted them in learning new words, memorizing word meaning, having a chance to choose their own words to learn, sharing words to classmates, working in a group, and realizing the importance of learning new words. The findings will help Thai EFL university students improve their vocabulary learning and generate an innovative body of knowledge regarding vocabulary instruction. Pedagogical implications are also suggested for EFL teachers who want to implement VSS in their vocabulary instruction.

Keywords: perceptions, Thai EFL undergraduate students, vocabulary instruction, vocabulary knowledge, vocabulary retention, Vocabulary Self-Collection Strategy (VSS)

Cite as: Raungsawat, N., \& Chumworatayee, T. (2021). The Effects of Vocabulary SelfCollection Strategy Instruction on Thai EFL Undergraduate Students' Vocabulary Knowledge and Perceptions Arab World English Journal, 12 (1) 253-269.

DOI: https://dx.doi.org/10.24093/awej/vol12no1.18 
Arab World English Journal (AWEJ) Volume 12. Number 1. March 2021

The Effects of Vocabulary Self-Collection Strategy Instruction

Raungsawat \& Chumworatayee

\section{Introduction}

Vocabulary is an essential component in learning a second language. Schmitt (2010) states that learners require a large vocabulary to function in a second language. Schmitt (2000) and Hsu (2006) point out that lexical knowledge is central to communicative competence. Mothe (2013) further explains that vocabulary is required for expressing thoughts, feeling, and meaning through productive and receptive skills. According to Wilkins (1972), learners of a second language who do not have sufficient vocabularies cannot understand others or express their own ideas.

However, research findings revealed that insufficient vocabulary knowledge is one of the main problems for Thai students in comprehending English texts, especially those at the tertiary level ( Wiriyakarun, 2018) . For example, Adunyarittigun ( 2002) found that inadequate vocabulary was one of the factors leading to Thai students' failure in predicting the meaning of unknown words in context. Akkakoson and Setobol (2009) revealed that most Thai students had limited vocabulary and could not interpret the word meanings, sentences and paragraphs. Similarly, Attaprechakul's (2013) research findings showed that Thai students faced problems in inferring unfamiliar word meanings from the context which resulted in understanding the meaning of the whole text. With regard to the aforementioned English reading problems, Thai EFL university students urgently need to improve vocabulary knowledge to facilitate their understanding of English reading materials. Hence, a number of vocabulary instructional methods employed to help increase students' vocabulary knowledge were reviewed. After the revision of literature and previous studies on vocabulary learning, the researchers found an interesting strategy called "Vocabulary Self-Collection Strategy" or "VSS" proposed by Haggard (1982).

Vocabulary Self-Collection Strategy (VSS) is an interactive-learning instructional strategy that "helps students increase their vocabulary so that they can become better readers, promotes the long-term acquisition of language in an academic setting" (Haggard, 1986, p.4). Through VSS, students are encouraged to select and study words from a reading text that are new and interesting. Then they use the context to determine word meaning, and nominate the words to be learned with members of the class (Antonacci \& O'Callaghan, 2012). It is believed that when learners are given a chance to choose their own vocabularies based on their interest, reading comprehension is enhanced (Haggard, 1986; Ruddell \& Shearer, 2002). Student-centered tasks of VSS: selecting, defining, finalizing, and using words (Antonacci \& O'Callaghan, 2012) help promote "content learning and independent word-learning strategies" (Harmon et al., 2005, p. 314). Simply put, VSS procedures support reading comprehension by developing both knowledge of word definitions and knowledge of the context in which the words are found (Haggard, 1982).

As the previous studies show, VSS has been successfully implemented with different levels of learners in cooperative group settings. However, none of the research has been carried out with Thai tertiary students. Therefore, this study mainly aims to examine Thai university students' vocabulary knowledge through VSS instruction. Additionally, the students' perceptions towards the implementation of VSS are investigated. The research findings will help Thai 
Arab World English Journal (AWEJ) Volume 12. Number 1. March 2021

The Effects of Vocabulary Self-Collection Strategy Instruction

Raungsawat \& Chumworatayee

undergraduate students to improve vocabulary learning and be a valuable guideline for further studies. To this end, two main research questions are proposed in this study as follows.

1. To what extent does Vocabulary Self-Collection Strategy (VSS) instruction affect Thai EFL undergraduate students' vocabulary knowledge?

2.

3. What are Thai EFL undergraduate students' perceptions towards Vocabulary SelfCollection Strategy (VSS) instruction?

4.

\section{Literature Review}

Vocabulary Knowledge

Vocabulary knowledge generally refers to knowledge of individual word meaning. Moreover, the meaning of a word is often associated with a learner's real-life experience, and its exact meaning depends on the context in which it appears. Thus, knowing a word may go beyond its definition found in a dictionary (Koda, 2005). It is widely accepted that vocabulary knowledge plays a vital role in students' success in learning a language because it is a crucial component of linguistic competence (Killic, 2019) and enables language use (Nation, 1993).

One distinction that has frequently been made in the recent literature on vocabulary learning between two primary aspects of vocabulary is breadth and depth of knowledge (Anderson and Freebody, 1981; Qian, 2002; Nassaji, 2006; Killic, 2019). The breadth of knowledge refers to the quantity or number of words that a learner knows at a certain level of language proficiency (Nation, 2001), whereas the depth of knowledge is defined as the quality of how well a learner knows a word (Read, 2000). Another well-known distinction regarding vocabulary knowledge is receptive and productive knowledge. The former means the ability to comprehend lexical items when listening or reading while the latter refers to what a learner needs to know about lexical items when speaking or writing (Schmitt, 2014). Nation (2013) provided three significant aspects of the vocabulary knowledge: form, meaning, and use. 'Form' means knowledge of spoken and written form of words. 'Meaning' entails an understanding of formmeaning relationships, concepts and referents of words, and its association with other words. 'Use' refers to knowing grammatical functions, collocations, and usage constraints of words.

\section{Vocabulary Self-Collection Strategy}

Haggard (1982) firstly introduced an approach to word learning called the Vocabulary Self-Collection Strategy (VSS) to develop students' highly refined, independent vocabulary development skills. In this strategy, students are put into cooperative groups to read an assigned reading to identify words that they think should be studied further or essential to understand a text. The definition of words can be discussed in a cooperative group before sharing them with the whole class. Simply put, the main components dealing with VSS include word choice and interest, word consciousness, using context clues, and group discussion.

VSS has been recognized in a similar way. Martin (2002) defines VSS as "an interactivelearning instructional strategy that promotes word awareness; it helps students to learn vocabulary words, and allow them to have an active role in their teaching and learning process" (p.29). As stated by Haggard (1986): 
Arab World English Journal (AWEJ) Volume 12. Number 1. March 2021

The Effects of Vocabulary Self-Collection Strategy Instruction

Raungsawat \& Chumworatayee

VSS helps students increase their vocabulary so that they can become better readers, promotes the long-term acquisition of language in an academic setting, and helps them to be able to learn a few key terms in depth rather than knowing much more superficially. (p.4)

Ruddell and Shearer (2002) claim that VSS "had the potential not only to reduce the limitations of traditional word learning instruction concerning student choice and motivation, but also to increase students' word awareness and strategic abilities for independent learning" ( p. 355). Antonacci and O'Callaghan (2012) add that VSS is employed to motivate students to learn new words by promoting " long-term acquisition and development of an academic discipline language" (p.26). Likewise, Ruddell (2005) indicates that VSS is intended to enhance long-term vocabulary growth and promote the acquisition and development of language of academic discipline. Manzo, Manzo, and Thomas (2005) describe VSS as "a cooperative structure that provides practice in identifying important terms and using context to predict meaning" (as cited in Kang \& Netto-Shek, 2017, pp. 174-175). To sum up, VSS is a vocabulary learning strategy that is used to promote vocabulary acquisition, word consciousness and long-term retention of academic vocabulary by motivating students to select their own vocabulary and work in a group to use contextual clues in order to derive the meaning of unknown words.

\section{Related Studies}

Several studies were carried out to investigate the perceptions towards VSS of the university students. Haggard (1986) analyzed 42 American university students' written responses from log entries after their word learning through VSS. The results revealed the strong motivation for learning new words, and VSS led them to become more sensitive to new words and more enjoyable in word learning. Moreover, the students developed their own systematic and independent strategies for learning new words.

Yanto (2017) examined the Indonesian tertiary students' responses towards learning research terminologies by using VSS. The results from the questionnaire showed that most students agreed that VSS helped them to better understand key words from their reading, supported them to learn how to understand words in contexts, motivated them to read a text, and encouraged them to apply the strategy across the curriculum in any content area. The students thought that VSS created collaborative learning, active learning, and improved their long-term memory of words.

To confirm the findings from the studies mentioned above, Ali (2017) described the Indonesian undergraduate students' perceptions on the use of VSS. The questionnaire results revealed that VSS helped them in learning new words, learning difficult words, and remembering words they have learned. Moreover, they thought that the strategy enhanced them to freely choose any words to learn, enriched their vocabulary knowledge, and made the learning of vocabulary more interesting.

Besides perceptions, many researchers conducted studies to assure the effectiveness of VSS by comparing VSS with other vocabulary instructions. Masoudi (2017) investigated the effects of VSS and Input Enhancement strategy on the vocabulary knowledge of Iranian EFL university students. The findings showed that learners who learned vocabulary using VSS had 
Arab World English Journal (AWEJ) Volume 12. Number 1. March 2021

The Effects of Vocabulary Self-Collection Strategy Instruction

Raungsawat \& Chumworatayee

higher vocabulary test mean scores than those exposed to the Input Enhancement strategy. Also, the students in the VSS group were more motivated to guess the unknown words.

Dowswell (2017) employed VSS to improve the vocabulary knowledge of university students in the UAE. The results revealed that the students who learned vocabulary with VSS outperformed those who studied with conventional teaching. Furthermore, they reported that VSS was useful for them in vocabulary learning, they liked using VSS as a way of learning new vocabulary, their motivation increased, and the strategy improved their sense of community in the class.

Similarly, Ali et al. ( 2018) implemented VSS to enhance the students' vocabulary knowledge. The results revealed that the Indonesian university students instructed with VSS performed better than those taught with traditional teaching. The students described that VSS is a meaningful strategy in learning vocabulary, which increased their chances to choose any words to be learned. Additionally, they thought that VSS improved their vocabulary knowledge, and felt more interested in learning new words.

According to previous studies, the researchers found that VSS has been implemented across many countries and showed positive vocabulary learning and perceptions. In Thailand, Yunita (2015) conducted classroom action research on VSS instruction. The results showed higher scores in the vocabulary posttest when compared to the pretest scores. The data obtained from classroom observation, field notes, and interviews revealed an increase in the students' participation and motivation during the vocabulary instruction. However, participants in the study of Yunita (2015) were EFL Thai first-grade students. Therefore, to fulfill the gap, the current study aims to examine the VSS's effects on vocabulary knowledge and perceptions of undergraduate students in Thailand.

\section{Research Methodology \\ Research Design}

The present study used mixed methods and experimental research design. Moreover, a one-group pretest-posttest design was employed since there was only one student group participating in this study.

\section{Participants}

The participants in this study were 38 second-year undergraduate English major students enrolling in English Reading for Academic Purposes course in Academic Year 2/2019 at a university in Thailand. Convenience sampling was employed for sample selection. Six males and thirty-two females, aged between 19-20 years old, participated in the study. They had mixed abilities according to the scores they got from the reading course they have taken previously.

\section{Reading Materials}

The reading passages were developed based on three aspects: students' preferences, text difficulty, and text length. For the students' preferences, the top three disciplines selected by the students were (1) cultural studies, (2) art, and (3) education. Regarding text difficulty, the Flesch Reading Ease scores of the passages were 60.1, 60.0, and 61.8, respectively. When aligning the scores to CEFR, it revealed that the reading passages were appropriate for the learners at B2 CEFR level or upper intermediate (Linguapress, 2020). Concerning the text length, the passage 
of cultural studies, art, and education comprises 1,029, 665, and 689 words, respectively. These lengths came from the average number of words in reading passages in renowned academic reading textbooks designed for the EFL university students at B2 CEFR levels. The reading tasks in each reading passage were developed based on three reading instruction phases: before reading, during reading, and after reading. VSS instruction was implemented in during and after reading phases.

\section{Research Instruments}

The data were collected through three research instruments, including vocabulary tests, a perception questionnaire, and semi-structured interview questions.

\section{Vocabulary Tests}

The vocabulary tests were used as a pretest, posttest, and delayed posttest. The aim was to assess the students' vocabulary knowledge before and after VSS instruction. The tests were constructed by adapting Gregersen (2001)' s vocabulary test. They consisted of academic vocabularies that are parts of the AWL at B2 CEFR level taken from three B2 CEFR level reading passages on cultural studies, art, and education. Totally, there were 30 academic vocabularies in the tests which were divided into two sections. The first section required the students to match each word with its definition. The second section provided sentences with missing words. To get a score for knowing the word, the students were required to match the word with its definition and complete the correct word into the sentence. The total scores of the tests were 30 points. The administration time for the tests was 45 minutes.

\section{Perception Questionnaire}

The questionnaire was adapted from the questionnaires designed by Yanto (2017) and Ali (2017). There were two parts in the questionnaire. The first part included 19 closed statements divided into the perceptions regarding the effects of VSS instruction on vocabulary knowledge and word consciousness. The participants were asked to rank their agreement level to the given statements ranging from 1 (Strongly disagree) to 5 (Strongly agree). The second part of the questionnaire consisted of two open-ended questions asking the participants regarding the strengths and weaknesses of VSS instruction.

\section{Semi-structured Interview}

A semi-structured interview was employed to elicit in-depth information of the results from the perception questionnaire on the VSS instruction. There were seven interview questions consisted of three aspects: the participants' opinions about vocabulary teaching in their previous English reading course, the benefits of VSS instruction, and the participants' suggestions about the activity in VSS instruction.

\section{Research Procedures}

This study was carried out in the course entitled English Reading for Academic Purposes. The participants took the vocabulary pretest in the first week. VSS instruction was implemented in Week 2 - 7. The total time of each lesson was 150 minutes. There were seven VSS instruction steps based on three phases of reading instruction, namely before reading, during reading, and after reading ( Figure one) . The vocabulary posttest was administered in Week 8. Then all participants were asked to complete the questionnaire to express perceptions towards the VSS 
instruction. Nine students were purposively selected to join the interview based on the interesting responses from the open-ended questionnaire. Fourteen days after the intervention, all participants were requested to take a vocabulary delayed posttest to measure their vocabulary retention.

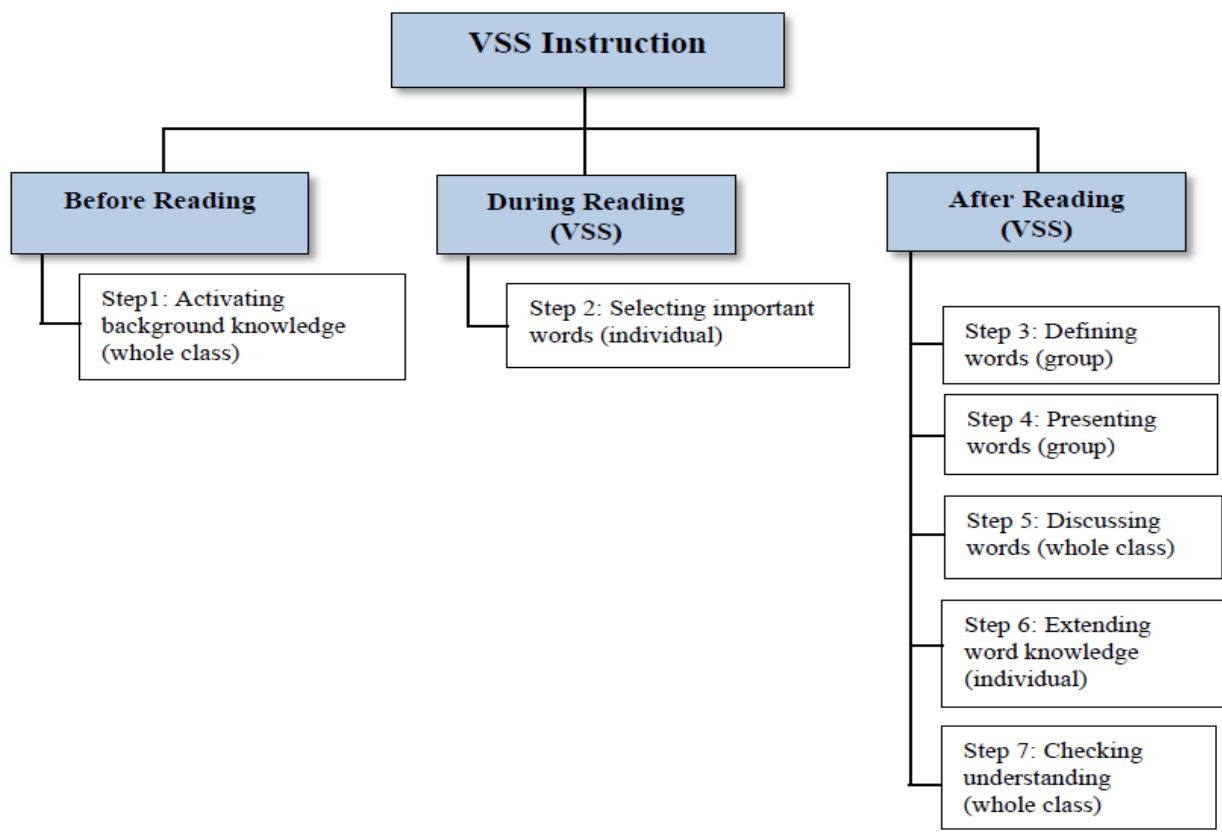

Figure 1. VSS Instruction Model (Adapted from Antonacci \& O'Callaghan, 2010; Martin, 2002; Ruddell, 2005; Tierney \& Readence, 2005)

\section{Results}

The results of the study are presented according to two aspects: vocabulary knowledge and perceptions towards VSS instruction.

\section{Vocabulary Knowledge}

Table one shows descriptive statistics of the vocabulary pretest and posttest. Out of 30 points, the mean score $(\overline{\mathrm{x}})$ of the vocabulary pretest was $8.50(\mathrm{SD}=4.70)$ while the vocabulary posttest had a higher mean score $(\overline{\mathrm{x}})$ at $12.18(\mathrm{SD}=4.71)$.

Table 1. Descriptive statistics of vocabulary pretest and posttest

\begin{tabular}{lcccc}
\hline & $\begin{array}{c}\text { Min } \\
(0)\end{array}$ & $\begin{array}{c}\text { Max } \\
(30)\end{array}$ & $\begin{array}{c}\text { Mean }(\overline{\mathbf{x}}) \\
(n=38)\end{array}$ & SD \\
\hline Pretest & 3 & 24 & 8.50 & 4.70 \\
Posttest & 6 & 26 & 12.18 & 4.71 \\
\hline
\end{tabular}


Arab World English Journal (AWEJ) Volume 12. Number 1. March 2021

Table two presents the paired samples $t$-test analysis of the vocabulary pretest and posttest. The difference between the mean score $(\overline{\mathrm{x}})$ of the vocabulary pretest and posttest was 3.68. The significant value (2-tailed) was .000 , which indicated that there was a statistically significant difference in vocabulary pretest and posttest scores at the .05 level.

Table 2 Paired samples $t$-test of vocabulary pretest and posttest

$$
\begin{aligned}
& \text { Paired Samples } t \text {-test } \\
& \text { 95\% Confidence } \\
& \text { Interval of the }
\end{aligned}
$$

Difference

\begin{tabular}{lcccccccc} 
& Mean & SD & SE & Lower & Upper & $\mathrm{t}$ & df & Sig. (2-tailed) \\
\hline $\begin{array}{l}\text { Pretest- } \\
\text { Posttest }\end{array}$ & -3.68 & 1.85 & .300 & -4.291 & -3.077 & -12.297 & 37 & .000 \\
\hline
\end{tabular}

$* p<.05$

The comparison of descriptive statistics of the vocabulary posttest and delayed posttest were illustrated in Table three. It revealed that the mean score $(\bar{x})$ of the vocabulary posttest and delayed posttest was $12.18(\mathrm{SD}=4.71)$ and $11.53(\mathrm{SD}=4.68)$, respectively.

Table 3 Descriptive statistics of vocabulary posttest and delayed posttest

\begin{tabular}{lcccc}
\hline & $\begin{array}{c}\text { Min } \\
(0)\end{array}$ & $\begin{array}{c}\text { Max } \\
(30)\end{array}$ & $\begin{array}{c}\text { Mean }(\overline{\mathbf{x}}) \\
(n=38)\end{array}$ & SD \\
\hline Posttest & 6 & 26 & 12.18 & 4.71 \\
Delayed Posttest & 5 & 26 & 11.53 & 4.68 \\
\hline
\end{tabular}

The paired samples $t$-test was used again to compare the mean score $(\overline{\mathrm{x}})$ of the vocabulary posttest and delayed posttest. Table four revealed the difference between the mean score $(\overline{\mathrm{x}})$ of the vocabulary posttest and delayed posttest was at .658. The results showed that the significant value (2-tailed) was .062, indicating no statistically significant difference in vocabulary posttest and delayed posttest mean scores at the .05 level. This can be implied that the students could retain vocabulary learned after VSS instruction.

Table 4 Paired samples $t$-test of vocabulary posttest and delayed posttest

$$
\begin{aligned}
& \text { Paired Samples } t \text {-test } \\
& \text { 95\% Confidence } \\
& \text { Interval of the } \\
& \text { Difference }
\end{aligned}
$$

\begin{tabular}{lcccccccc} 
& Mean & SD & SE & Lower & Upper & t & df & Sig. (2-tailed) \\
\hline $\begin{array}{llllllll}\text { Posttest }- \\
\begin{array}{l}\text { Delayed Posttest } \\
(n=38)\end{array}\end{array}$ & .658 & 2.109 & .342 & .035 & 1.351 & 1.923 & 37 & .062 \\
\hline$* p<.05$ & & & & & & & \\
\hline
\end{tabular}


Arab World English Journal (AWEJ) Volume 12. Number 1. March 2021

The Effects of Vocabulary Self-Collection Strategy Instruction

Raungsawat \& Chumworatayee

\section{Perceptions towards VSS Instruction}

Results from Questionnaire

The total mean score of statements in the questionnaire was 4.4 with SD of 0.11 as shown in Table five. Regarding vocabulary knowledge, the mean score was 4.41 with SD of 0.09 . In terms of word consciousness, the mean score was 4.47 and SD 0.14. The results from the total mean scores of vocabulary knowledge and word consciousness demonstrate that the participants mostly strongly agreed to the statements in the questionnaire.

Table 5 Descriptive statistics of the perception questionnaire $(N=38)$

\begin{tabular}{ccc}
\hline & Mean & SD \\
\cline { 2 - 3 } Vocabulary knowledge & 4.41 & 0.09 \\
Word consciousness & 4.47 & 0.14 \\
\hline Total & 4.44 & 0.11 \\
\hline
\end{tabular}

Table 6 Descriptive statistics of statements on vocabulary knowledge

\begin{tabular}{|c|c|c|}
\hline Statement & Mean & SD \\
\hline $\begin{array}{l}\text { 1. I can learn new words through Vocabulary Self-Collection } \\
\text { Strategy. }\end{array}$ & 4.53 & 0.61 \\
\hline $\begin{array}{l}\text { 2. I can remember words that I have learned through Vocabulary } \\
\text { Self-Collection Strategy. }\end{array}$ & 4.45 & 0.51 \\
\hline $\begin{array}{l}\text { 3. I can retain my long-term memory of words through Vocabulary } \\
\text { Self-Collection Strategy. }\end{array}$ & 4.52 & 0.65 \\
\hline $\begin{array}{l}\text { 4. I can learn vocabulary more meaningfully through Vocabulary } \\
\text { Self-Collection Strategy. }\end{array}$ & 4.42 & 0.66 \\
\hline $\begin{array}{l}\text { 5. I think learning vocabulary becomes a more interesting activity } \\
\text { through Vocabulary Self-Collection Strategy. }\end{array}$ & 4.47 & 0.66 \\
\hline $\begin{array}{l}\text { 6. I think Vocabulary Self-Collection Strategy enriches my } \\
\text { vocabulary knowledge. }\end{array}$ & 4.53 & 0.61 \\
\hline $\begin{array}{l}\text { 7. I think Vocabulary Self-Collection Strategy is good to be applied } \\
\text { in a vocabulary classroom. }\end{array}$ & 4.39 & 0.77 \\
\hline $\begin{array}{l}\text { 8. I think I am a better reader through Vocabulary Self-Collection } \\
\text { Strategy as I understand key words in depth from my reading. }\end{array}$ & 4.29 & 0.72 \\
\hline $\begin{array}{l}\text { 9. I think Vocabulary Self-Collection Strategy helps me learn how } \\
\text { to understand word meaning in the context. }\end{array}$ & 4.37 & 0.69 \\
\hline $\begin{array}{l}\text { 10. I better understand how I can make text more comprehensible } \\
\text { through Vocabulary Self-Collection Strategy. }\end{array}$ & 4.29 & 0.68 \\
\hline Total & 4.41 & 0.09 \\
\hline
\end{tabular}

Table six shows that top three statements of vocabulary knowledge were Item one, "I can learn new words through Vocabulary Self-Collection Strategy." and item six, "I think Vocabulary Self-Collection Strategy enriches my vocabulary knowledge." had the highest and same mean scores (4.53) and SD (0.61). Item three, "I can retain my long-term memory of words through Vocabulary Self-Collection Strategy." had the second-highest mean score at 4.52 with SD of 0.65. The third- highest mean score (4.47, SD 0.66) was item five, "I think learning vocabulary 
Arab World English Journal (AWEJ) Volume 12. Number 1. March 2021

The Effects of Vocabulary Self-Collection Strategy Instruction

Raungsawat \& Chumworatayee

becomes a more interesting activity through Vocabulary Self-Collection Strategy." Item eight, "I think I am a better reader through Vocabulary Self-Collection Strategy as I understand key words in depth from my reading." and Item 10, "I better understand how I can make text more comprehensible through Vocabulary Self-Collection Strategy." had the lowest and same mean scores at 4.29 with S.D 0.72 and 0.68 respectively. The item with the second lowest mean score (4.37, SD 0.69) was Item nine, "I think Vocabulary Self-Collection Strategy helps me learn how to understand word meaning in the context." Item seven, "I think Vocabulary Self-Collection Strategy is good to be applied in a vocabulary classroom." had the third lowest mean score at 4.39 with SD of 0.77 .

Table 7 Descriptive statistics of statements on word consciousness

\begin{tabular}{lcc}
\hline \multicolumn{1}{c}{ Statement } & Mean & SD \\
\hline $\begin{array}{l}\text { 11. I like selecting and collecting new or difficult words from the } \\
\text { reading text. }\end{array}$ & 4.32 & 0.86 \\
$\begin{array}{l}\text { 12. I like to share my chosen words with my classmates. } \\
\text { 13. I am satisfied when the teacher gives me a freedom to choose }\end{array}$ & 4.21 & 0.74 \\
words that I want to learn. & & 0.49 \\
$\begin{array}{l}\text { 14. I am more interested in new words through Vocabulary Self- } \\
\text { Collection Strategy. }\end{array}$ & 4.50 & 0.66 \\
$\begin{array}{l}\text { 15. I like to learn vocabulary based on my own choice. } \\
\text { 16. I am motivated to guess the word meaning in a text through }\end{array}$ & 4.47 & 0.82 \\
$\begin{array}{l}\text { Vocabulary Self-Collection Strategy. } \\
\text { 17. I think Vocabulary Self-Collection Strategy enhances my word }\end{array}$ & 4.39 & 0.82 \\
$\begin{array}{l}\text { awareness. } \\
\text { 18. I think Vocabulary Self-Collection Strategy creates } \\
\text { collaborative learning. }\end{array}$ & 4.71 & 0.65 \\
19. I am very happy when the teacher explains my selected words. & 4.61 & 0.61 \\
\hline$\quad$ Total & 4.47 & 0.14 \\
\hline
\end{tabular}

For word consciousness (Table seven), the top three statements included Item 13, "I am satisfied when the teacher gives me a freedom to choose words that I want to learn." (mean score 4. 79, SD 0.49), Item 18 “I think Vocabulary Self-Collection Strategy creates collaborative learning." (mean score 4.71, SD 0.47), and Item 19, "I am very happy when the teacher explains my selected words." (mean score 4.61, SD 0.61) respectively. In terms of the bottom three items, Item 12, "I like to share my chosen words with my classmates." had the lowest mean score at 4.21 with SD of 0.74 . Item 16, "I am motivated to guess the word meaning in a text through Vocabulary Self-Collection Strategy." had the second-lowest mean score at 4.26 with SD 0.82. The third-lowest mean score was Item 11, "I like selecting and collecting new or difficult words from the reading text." (mean score 4.32, SD 0.86). Although the questionnaire items had slightly different mean scores, they were all interpreted in the same way. That is, the majority of the participants strongly agreed to the statements.

The second part of the questionnaire consisted of two open-ended questions. The first question in this section was, "In your opinion, what is the strong point of Vocabulary SelfCollection Strategy?" The students' perceptions regarding the strengths of VSS can be classified into seven themes in the order of frequency, as displayed in Table eight. 
Arab World English Journal (AWEJ) Volume 12. Number 1. March 2021

The Effects of Vocabulary Self-Collection Strategy Instruction

Raungsawat \& Chumworatayee

Table 8 Students' opinions on the strengths of Vocabulary Self-Collection Strategy

\begin{tabular}{clc}
\hline Theme & \multicolumn{1}{c}{ Strengths of VSS } & Frequency \\
\hline 1 & Help learn new words & 20 \\
2 & Have a chance to select interesting words & 16 \\
3 & Foster word memorization & 9 \\
4 & Better guess word meaning & 6 \\
5 & Be easier to learn vocabulary & 5 \\
6 & Practice working in a group & 2 \\
7 & Be able to consult the teacher immediately & 1 \\
\hline
\end{tabular}

The second open-ended question in the questionnaire was, "In your opinion, what is the weak point of Vocabulary Self-Collection Strategy?" Table nine shows ten themes that emerged from the analysis of data in the order of frequency.

Table 9 Students' opinions on the weaknesses of Vocabulary Self-Collection Strategy

\begin{tabular}{clc}
\hline Theme & \multicolumn{1}{c}{ Weaknesses of VSS } & Frequency \\
\hline 1 & Lead to wrong word meaning & 12 \\
2 & Be difficult to guess word meaning & 10 \\
3 & Not able to memorize all vocabularies & 4 \\
4 & Miss out other vocabularies from selection & 4 \\
5 & Take a long time & 3 \\
6 & Be able to share only some ideas and fear to answer in the presentation & 2 \\
7 & Not match between the selected words and the teacher's purposes & 2 \\
8 & Interrupt reading & 1 \\
9 & Not focus on grammar & 1 \\
10 & Not realizing the importance of the selected words if they are not used in & 1 \\
& real life & \\
\hline
\end{tabular}

The data collected from closed-statements and open-ended statements in the questionnaire showed the consistent results. Regarding vocabulary knowledge, Item one, "I can learn new words through Vocabulary Self-Collection Strategy." had the highest mean scores at 4.53 , indicating that most participants strongly agreed with this statement. Similarly, the theme with the highest frequency for the strengths of VSS is VSS "helps learn new words." For word consciousness, the participants rated their agreement to Item 13, "I am satisfied when the teacher gives me a freedom to choose words." with the highest mean score (4.79), which demonstrates that the majority of the participants strongly agreed to the statement. This finding is in accordance with the result from the participants' responses regarding the strong point of VSS. That is to say, most of them identified that they "have a chance to select interesting words" by themselves through the use of VSS. Moreover, various themes of the benefits of VSS were found in many closed-ended statements. For example, the theme "Foster word memorization" is shown in Item three, "I can retain my long-term memory of words through Vocabulary SelfCollection Strategy". Also, the theme "Practice working in a group" is appeared in Item 18, "I think Vocabulary Self-Collection Strategy creates collaborative learning." 
Arab World English Journal (AWEJ) Volume 12. Number 1. March 2021

The Effects of Vocabulary Self-Collection Strategy Instruction

Raungsawat \& Chumworatayee

\section{Results from Semi-Structured Interview \\ Opinions towards Vocabulary Teaching in Previous Reading Classes}

The first interview question was "How is vocabulary taught to you in your previous English classes? What is your opinion towards that?" The findings revealed that the participants mostly experienced traditional vocabulary instruction or decontextualized teaching methods in the past English reading courses.

\section{Benefits of VSS Instruction}

The second question in the interview was, "Do you find Vocabulary Self-Collection Strategy instruction beneficial for you? If so, how?" All respondents found VSS instruction useful for them in encouraging vocabulary learning, memorizing word meanings, better understanding word meaning in different contexts, having a chance to share words to classmates, and using learned vocabularies in the future.

The third question was, "Do you think Vocabulary Self-Collection Strategy instruction help you to develop vocabulary knowledge? If so, how?" The participants had similar opinions that VSS instruction improved their vocabulary knowledge for many reasons. They agreed that they could better memorize vocabularies because the strategy allowed them to guess the meanings of vocabularies from the context. Additionally, it gave them to freely select the vocabularies that they really want to know and share them with their peers.

The fourth question was, "Do you think Vocabulary Self-Collection Strategy instruction makes you retain vocabulary that you learned in the class? If so, how?" The participants revealed that when they selected vocabularies from their own interest, they could memorize those in a long period of time.

The fifth question was, "Do you think Vocabulary Self-Collection Strategy instruction assist you to be more aware of learning new vocabulary? If so, how?" The participants thought that VSS instruction enhanced their awareness in vocabulary learning. They realized the importance of learning new vocabularies because the strategy stimulated them to learn by themselves. They also paid special attention to keywords in the context. Moreover, they had more intention in learning vocabularies since they searched for vocabularies based on their interest.

The sixth question was, " Do you like Vocabulary Self-Collection Strategy instruction taught in the class? If so, why?" Every respondent liked VSS instruction. They had fun and felt interested more when they could choose their own words to learn. The strategy helped them find keywords, guess word meanings, cooperate with the classmates, and share vocabularies with the class.

\section{Suggestions about the Activity in VSS Instruction}

The last question of the interview was, "What do you think should be added more to Vocabulary Self-Collection Strategy instruction?" Some respondents thought that there was nothing to add more because the strategy was useful for them. However, many of them suggested that other vocabulary activities related to games and songs should be integrated to help the 
Arab World English Journal (AWEJ) Volume 12. Number 1. March 2021

The Effects of Vocabulary Self-Collection Strategy Instruction

Raungsawat \& Chumworatayee

students better memorize vocabularies. Also, the teacher should explain more the parts of words such as prefixes, suffixes as well as how to translate the meaning of words in different contexts.

To conclude, the findings from the semi-structured interview revealed that the participants mainly received conventional vocabulary teaching in previous reading classes. They thought that VSS instruction is beneficial for them in enhancing vocabulary knowledge and raising their awareness in vocabulary learning. They also suggested integrating other vocabulary activities such as games and songs into VSS instruction to improve long-term memory.

The questionnaire and the interview showed the similar results. The participants indicated that VSS instruction supported them in learning new words, memorizing word meaning, having a chance to choose their own words to learn, sharing words to classmates, working in a group, and realizing the importance of learning new words.

\section{Discussion}

The present study aimed to investigate the effects of VSS instruction on Thai EFL university students' vocabulary knowledge and perceptions. The findings revealed the effectiveness of VSS instruction on both variables. The result of the study regarding vocabulary knowledge is in line with previous studies conducted by Masoudi (2017), Dowswell (2017) and Ali et al. (2018). This can be due to the differences between VSS instruction and the traditional vocabulary teaching approach. Conventionally, the primary teaching methods in an English reading class include lectures for the whole group, rote memorization, grammar-translation, and examination-oriented methods. These activities might not sufficiently promote students' intrinsic motivation in language learning. On the contrary, VSS instruction provided the students with learner-centered activities as Ali et al. (2018) states that VSS is considered as the type of independent learning which is used to support student-centered learning method (SCL) because the students have an opportunity to choose and collect words based on their want and need. The student-centered tasks of VSS helped the students in the current study improve their vocabulary knowledge.

The finding relevant to the students' perceptions towards VSS instruction is consistent with the study of Yanto (2017) and Ali (2017). The questionnaire results in the present and the past research showed that the students mostly agreed that they could learn new words, increased their vocabulary knowledge, and retained their long-term memory through VSS. However, it is noticeable that the students rated Item eight, "I think I am a better reader through VSS as I understand key words in depth from my reading." and Item 10, "I better understand how I can make text more comprehensible through VSS." as the third lowest rank. These statements were supported by the response from one of the participants who described that VSS interrupted her reading because while she focused more on the words she was interested in, she sometimes missed the main point of the reading passage. This might be due to the reason provided by Hulstijn et al. (1996), explaining that when learners derive the targeted word meaning from context, they may decide to ignore other unknown words because they judge those words unnecessary for comprehension. Therefore, the overall understanding of the reading text might not be reached because the readers pay less attention to other details in the passage.

Besides, the results from the questionnaire revealed that Item 18, "I think VSS creates collaborative learning." had the second highest mean score. The students thought that working in 
Arab World English Journal (AWEJ) Volume 12. Number 1. March 2021

The Effects of Vocabulary Self-Collection Strategy Instruction

Raungsawat \& Chumworatayee

a group with their peers through VSS is a way to support each other in vocabulary learning. Nonetheless, they rated Item 12, "I like to share my chosen words with my classmates." as the final rank. This can be interpreted that they perceived that VSS enhanced word learning through working together, but in practice, they did not really want to share their chosen words with their classmates. This point can be explained based on Thai students' culture and behavior in working in a group. Many Thai students, especially those who have low English proficiency levels, lack confidence in sharing their ideas and fear of mistakes. Furthermore, they are unwilling to be intimidated by their friends if they present incorrect word meanings to the group. These could block the process of word learning through a collaborative group.

With regard to motivation, the students in the present study rated Item 16, "I am motivated to guess the word meaning in a text through VSS." as the second-lowest rank. The result of this study is not in line with the study of Haggard (1986), which revealed the strong motivation of the students in learning words through VSS. This might be because the students in Haggard's ( 1986) study were asked to collect the words they were interested to learn from various sources outside the classroom based on their own experiences such as magazines and newspapers, and then they were required to bring the words to discuss with their classmates. Therefore, they might have more independence in choosing their own words and more internal motivation in guessing the meanings of the words. As Chin (2004) states, internal motivation significantly stimulates vocabulary acquisition and improvement.

\section{Pedagogical Implications}

The findings of this study shed light on the efficacy of VSS. The study provided the empirical evidence that VSS can promote the undergraduate students' vocabulary knowledge and perceptions. Some pedagogical implications are suggested to EFL teachers who decide to integrate VSS in their vocabulary instruction. First, teachers should provide understanding of VSS to students in terms of its purposes and procedures. Moreover, the benefits of VSS should be discussed in the class to help raise students' awareness regarding the importance of the strategy. Second, since VSS requires the use of contextual clues to establish the meaning of unknown words, teachers should train students to derive word meanings from context to prepare students of how to use contextual clues and to ensure that they will not have a problem in using context during VSS instruction. Finally, teachers should not only allow students to select words that they are interested in and important to them from reading texts used in the class, but they should also provide more chances to students in selecting words based on their individual experiences and world knowledge from other reading sources outside the class. This encourages students' independent learning and motivation in learning new words.

\section{Conclusion}

VSS studies have been conducted with learners ranging from primary to university levels. However, no empirical research on VSS was carried out with Thai tertiary students. This paper aimed to investigate the effectiveness of VSS instruction on Thai undergraduate students' vocabulary knowledge and perceptions. The findings revealed that VSS is worth integrating into the Thai university context to improve the students' vocabulary learning. As Haggard (1986) states, VSS helps students increase their vocabulary so that they can become better readers, promote long-term retention of vocabulary in an academic setting. This is because the strategy 
Arab World English Journal (AWEJ) Volume 12. Number 1. March 2021

The Effects of Vocabulary Self-Collection Strategy Instruction

Raungsawat \& Chumworatayee

motivates students to select their own vocabulary and work in a group to use contextual clues to derive the meaning of unknown words.

It is recommended for researchers of further studies to consider the suitable way in participant selection. In an EFL context, VSS might be more appropriate for the students who have sufficient reading skills and language knowledge in order to apply the strategy effectively. Besides, this study employed one- group pretest-posttest design because there was only one group of the students enrolling in the English Reading for Academic Purposes course. Therefore, research in the future should include a control group to compare the effectiveness of VSS instruction with traditional vocabulary teaching. Also, VSS instruction in the current study was implemented for only eight weeks because of the limited time frame of the study. Further studies should expand the duration in data collection to see whether VSS instruction can enhance the students' vocabulary knowledge in a more extended period. Also, based on the suggestions about the activity in VSS instruction from the participants in this study, it is suggested that further research should integrate other vocabulary activities such as games and songs to enhance students' word learning and memorization.

\section{About the Authors \\ Nuntiporn Raungsawat is a full-time lecturer at English Department, Faculty of Humanities and Social Sciences, Rajabhat Rajanagarindra University. She is currently a Ph.D. candidate in English Language Teaching at Thammasat University, Thailand. Her areas of interests are EFL reading instruction and English language teaching.}

ORCID: https://orcid.org/0000-0002-5331-9600

Dr. Tipamas Chumworatayee (Associate Professor) teaches both post- and undergraduate courses at the Language Institute, Thammasat University, Thailand. She obtained her Ph.D. from Department of Reading, College of Education, Texas Woman's University, Texas, USA. Her main interests include ELT methodology, ELT teacher training, EFL reading-strategy instruction, and EFL reading strategy awareness raising.

\section{References}

Adunyarittigun, D. (2002) . An investigation of factors affecting English language reading success: A case study of an EFL College Reader. Thammasat Review, 7(1), 244-271.

Akkakoson, S., \& Setobol, B. (2009). Thai EFL students' use of strategies in reading English texts. The Journal of KMUTNB, 19(3), 329-342.

Ali, S. (2017). The students' interest on the use of Vocabulary Self-Collection Strategy in learning English vocabulary. Journal of Language Teaching and Literature, 4(2), 165174. https://doi.org/10.30605/ethicallingua.v4i2.630

Ali, S., Bazergan, E., \& Imran, N. (2018). The implementation of vocabulary self-collection strategy (VSS) to enrich students' vocabulary. Retrieved from http://pingpdf.com/pdfpenerapan-vocabulary-self-collection-strategy-vss-pasca-unhas.html.

Anderson, R. C., \& Freebody, P. ( 1981). Vocabulary knowledge. In J. Guthrie ( Ed. ), Comprehension and Teaching: Research Reviews (pp.77-117). Newark, DE: International Reading Association.

Antonacci, P., \& O'Callaghan, C. M. (2012). Promoting Literacy Development: 50 ResearchBased Strategies for K-8 Learners. London: Sage Publications. 
Arab World English Journal (AWEJ) Volume 12. Number 1. March 2021

Attaprechakul, D. (2013). Inference strategies to improve reading comprehension of challenging texts. English Language Teaching, 6(3), 82-91.

Chin, C. ( 2004) . EFL learners' vocabulary development in the real world: interests and preferences. English Teaching. Anseongunn, South Korea, 59(2), 43-58.

Crow, J. H. (1986). Receptive vocabulary acquisition for reading comprehension. The Modern Language Journal, 70(3), 242-250.

Dowswell, K. (2017) . Developing students' vocabulary knowledge in content subjects: A computational linguistic approach. Proceedings of The Ninth International Conference on Mobile, Hybrid, and On-line Learning (pp.41-46). Nice, France. https://www.iaria.org/conferences2017/eLmL17.html

Gregersen, L. (2001). Vocabulary self-collection strategy for primary readers. Texas State University. Retrieved from https://citeseerx.ist.psu.edu

Haggard, M. R. (1982). The vocabulary self-collection strategy: An active approach to word learning. Journal of Reading, 26, 203-207.

Haggard, M. R. (1986). The vocabulary self-collection strategy: Using student interest and word knowledge to enhance vocabulary growth. Journal of Reading, 29(7), 634-642.

Harmon, J. M., Hedrick, W. B., Wood, K. D., \& Gress, M. (2005). Vocabulary self-collection: A study of middle-school students word selections from expository text. Reading Psychology, 26(3), 313-333. https://doi.org/10.1080/02702710590969689

Hsu, J. T. (2006) . Teaching English Lexically: The University Word List is a Good Start. Proceedings of 2006 Taiwan TESOL Conference, (pp.53-64). Huwei, Yun-lin, Taiwan. https://www. ukessays.com/essays/english-language/motivation-and-vocabulary-learningenglish-language-essay.php?vref=1

Hulstijn, J. H., Hollander, M., \& Greidanus, T. ( 1996) . Incidental vocabulary learning by advanced foreign language students: The influence of marginal glosses, dictionary use, and reoccurrence of unknown words. The Modern Language Journal, 80(3), 327-339. https://doi.org/10.1111/j.1540-4781.1996.tb01614.x

Kang, N., \& Netto-Shek, J. (2017). Teaching vocabulary at the upper primary level with the vocabulary self-selection strategy. Beyond Words, 5(2), 116-135.

https://doi.org/10.33508/bw.v5i2.1592

Kilic, M. (2019). Vocabulary knowledge as a predictor of performance in writing and speaking: A case of Turkish EFL learners. PASAA, 57, 133-164.

Koda, K. (2005) . Insights into Second Language Reading: A Cross-Linguistic Approach. Cambridge: Cambridge University Press.

Linguapress. (2020). Flesch-Kincaid, other readability scales and their relevance for the EFL/ESL class. https://linguapress.com/teachers/flesch-kincaid.htm.

Martin, A. ( 2002) . Essential Strategies for Teaching Vocabulary: A Brief Overview of Vocabulary Development. Retrieved from http: / / / www. vocabulary self-collection strategy.pdf.

Masoudi, G. (2017). The Effect of Vocabulary Self -Selection Strategy and Input Enhancement Strategy on the Vocabulary Knowledge of Iranian EFL Learners. English Language Teaching, 10(8), 32-42.

Mothe, P. S. (2013). Innovative techniques of teaching vocabulary at the intermediate level in the second language classroom. Proceedings of FLLT Conference (pp.377-390). Bangkok, Thailand. http://www.litu.tu.ac.th/journal/FLLTCP/Proceeding/377.pdf 
Arab World English Journal (AWEJ) Volume 12. Number 1. March 2021

The Effects of Vocabulary Self-Collection Strategy Instruction

Raungsawat \& Chumworatayee

Nassaji, H. (2006). The relationship between depth of vocabulary knowledge and L2 learners' lexical inferencing strategy use and success. The Modern Language Journal, 90(3), 387401. https://doi.org/10.1111/j.1540-4781.2006.00431.x

Nation, I. S. P, (2013). Learning Vocabulary in Another Language. Cambridge: Cambridge University Press.

Nation, I. S. P. (1993). Vocabulary size, growth, and use. In R. Schreuder, \& B. Weltens (eds.), The Bilingual Lexicon (pp. 115-134). Amsterdam: John Benjamins.

Nation, I. S. P. (2001). Learning vocabulary in another language. Cambridge: Cambridge University Press.

Qian, D. V. (2002). Investigating the relationship between vocabulary knowledge and academic reading performance: An assessment perspective. Language Learning, 52(3), 513-536. https://doi.org/10.1111/1467-9922.00193

Read, J. (2000). Assessing vocabulary. Cambridge: Cambridge University Press.

Ruddell, M. R. (2005). Teaching Content Reading and Writing ( $4^{\text {th }}$ ed.). United State: John Wiley.

Ruddell, M. R., \& Shearer, B. A. (2002) . "Extraordinary" , " tremendous” , " exhilarating", " magnificent" : Middle school at-risk students become avid word learners with the Vocabulary Self-Collection Strategy (VSS). Journal of Adolescent \& Adult Literacy, 45(5), 352-63.

Schmitt, N. (2000) Vocabulary in Language Teaching. Cambridge University Press, Cambridge.

Schmitt, N. (2010). Key issues in teaching and learning vocabulary. In R. Chacón-Beltrán, C. Abello-Contesse, M. Torreblanca-López, ( eds. ), Insights into Non-native Vocabulary Teaching and Learning, (pp. 28-40). Bristol, UK: Multilingual Matters.

Schmitt, N. (2014) . Size and depth of vocabulary knowledge: What the research shows. Language Learning, 64(4), 913-951.

Tierney, R. J., \& Readence, J. (2005). Reading strategies and practices: A compendium. ( $6^{\text {th }}$ Ed.). Boston: Allyn \& Bacon.

Wilkins, D. (1972). Linguistics in Language Teaching. London: Arnold.

Wiriyakarun, P. ( 2018) . Examining Thai EFL learner's knowledge of academic English vocabulary. The Liberal Arts Journal, Mahidol University, 1(1), 119-132. Retrieved from https://so02.tci-thaijo.org/index.php/lajournal/article/view/242496

Yanto, E. S. (2017). Implementing Vocabulary Self-Collection Strategy in the EFL classroom in engaging students' communicative classroom. Journal of Teaching \& Learning English in Multicultural Contexts, 1(2), 14-22.

Yunita, F. (2015). Improving English vocabulary mastery through vocabulary self-collection strategy of the first-grade students of Muttawasith at Addirasat Islamiah School Laddua Panarea Pattani South of Thailand, (Unpublished Bachelor Thesis). Iain Tulungagung University, Indonesia. 